\title{
“In-Loop" $\left[{ }^{11} \mathrm{C}\right] \mathrm{CO}_{2}$-Fixation: Prototype and Proof-of-Concept
}

\author{
Kenneth Dahl ${ }^{1}$, Thomas L. Collier ${ }^{1,2}$, Ran Chang ${ }^{1}$, Xiaofei Zhang ${ }^{1}$, Oleg Sadovski ${ }^{3}$, Steven \\ H. Liang ${ }^{1, *}$, and Neil Vasdev ${ }^{1,{ }^{*}}$ \\ ${ }^{1}$ Division of Nuclear Medicine and Molecular Imaging, Massachusetts General Hospital, and \\ Department of Radiology, Harvard Medical School, 55 Fruit Street, Boston, MA 02114, USA \\ ${ }^{2}$ Advion Inc., 10 Brown Road, Ithaca, NY 14850, USA \\ ${ }^{3}$ Research Imaging Centre, Centre for Addiction and Mental Health, 250 College Street, Toronto, \\ Ontario, Canada MST 1 R8
}

\section{Abstract}

Carbon-11 labelled carbon dioxide is the most common feedstock for the synthesis of positron emission tomography radiotracers, and can be directly used for ${ }^{11} \mathrm{C}$-carbonylation. Herein, we report the development of an apparatus that takes advantage of "in-loop" technologies to facilitate robust and reproducible syntheses of ${ }^{11} \mathrm{C}$-carbonyl-based radiotracers by $\left[{ }^{11} \mathrm{C}_{\mathrm{CO}_{2}}\right.$-fixation. Our "in-loop" $\left[{ }^{11} \mathrm{C}\right] \mathrm{CO}_{2}$-fixation method is simple, efficient, and proceeds smoothly at ambient pressure and temperature. We selected model ${ }^{11} \mathrm{C}$-carbonyl labelled carbamates as well as symmetrical and unsymmetrical ureas based on their widespread use in radiotracer design and our clinical research interests for proof-of-concept. Utility of this method is demonstrated by the synthesis of a reversible radiopharmaceutical for monoamine oxidase B, $\left[{ }^{11} \mathrm{C}\right] \mathrm{SL} 25.1188$, as well as two novel fatty acid amide hydrolase inhibitors. These radiotracers were isolated and formulated ( $>3.5 \mathrm{GBq} ; 100 \mathrm{mCi}$ ) with radiochemical purities (>99\%) and molar radioactivity ( $>80$ $\mathrm{GBq} / \mu \mathrm{mol} ; \geq 2162 \mathrm{mCi} / \mu \mathrm{mol})$.

\section{Keywords}

$\mathrm{CO}_{2}$-fixation; FAAH; MAO-B; Carbonylation; Carbon-11; Loop

\section{Introduction}

Carbon-11 $\left({ }^{11} \mathrm{C} ; \mathrm{t}_{1 / 2}=20.4 \mathrm{~min}\right)$ is a valuable radionuclide in positron emission tomography (PET). ${ }^{1-4}$ The high positron emission decay mode $\left(\beta^{+} ; 99.8 \%\right)$ and low energy protons $(0.96$ $\mathrm{keV}$ ) allow for high resolution in-vivo imaging. Another advantage is that ${ }^{11} \mathrm{C}$ can be incorporated into bioactive or endogenous molecules without any structural modification (isotopologue of carbon-12) and with minimal effect on the (bio)chemical properties of the compound. Moreover, the short half-life of ${ }^{11} \mathrm{C}$ allows for multiple in vivo PET imaging studies to be undertaken in the same subject or animal on a single day. The most widely used reaction in ${ }^{11} \mathrm{C}$-radiopharmaceutical production is ${ }^{11} \mathrm{C}$-methylation, via $\left[{ }^{11} \mathrm{C}\right] \mathrm{CH}_{3} \mathrm{I}$ or

\footnotetext{
* liang.steven@mgh.harvard.edu; vasdev.neil@mgh.harvard.edu; Fax: +1 617-726-6165; Tel: +1 617-643-4736.
} 
$\left[{ }^{11} \mathrm{C}_{\mathrm{CH}_{3}} \mathrm{OTf}\right.$. However ${ }^{11} \mathrm{C}$-carbonylation is also a viable strategy using $\left[{ }^{11} \mathrm{C}_{\mathrm{CO}}\right.$, $\left[{ }^{11} \mathrm{C}\right] \mathrm{CO},\left[{ }^{11} \mathrm{C}\right] \mathrm{COCl}_{2}$ or $\left[{ }^{11} \mathrm{C}\right] \mathrm{HCN} .{ }^{5}$

$\left[{ }^{11} \mathrm{C}_{\mathrm{CO}_{2}}\right.$ is a highly attractive building block for radiolabelling, since it is produced directly in target. However, due to low chemical reactivity and trapping efficiency, the direct incorporation of $\left[{ }^{11} \mathrm{C}\right] \mathrm{CO}_{2}$ into organic molecules poses a significant challenge. The traditional methods for " $\left[{ }^{11} \mathrm{C}_{\mathrm{CO}_{2}}\right.$-fixation" rely on Grignard reagents, organolithiums or organosilanamines. ${ }^{5}$ All such reagents require the rigorous exclusion of atmospheric moisture and $\mathrm{CO}_{2}$ during storage and manipulation. The direct formation of ${ }^{11} \mathrm{C}$-labelled carbonyl groups by $\left[{ }^{11} \mathrm{C}_{\mathrm{CO}_{2}}\right.$-fixation, has been recently established in radiopharmaceutical production, ${ }^{5-6}$ where strong organic bases, e.g. 1,8-Diazabicyclo[5.4.0]undec-7-ene (DBU) ${ }^{7}$ or 2-tert-Butylimino-2-diethylamino-1,3-dimethylperhydro-1,3,2-diazaphosphorline (BEMP), ${ }^{8-9}$ are utilized to reversibly capture $\left[{ }^{11} \mathrm{C}\right] \mathrm{CO}_{2}$ in solution. While initial work focused on the synthesis of ${ }^{11} \mathrm{C}$-labelled carbamates, the scope of the method rapidly extended to syntheses of unsymmetrical $\left[{ }^{11} \mathrm{C}\right]$ ureas and $\left[{ }^{11} \mathrm{C}\right]$ oxazolidinones via $\mathrm{POCl}_{3}$ dehydration to generate ${ }^{11} \mathrm{C}$-labelled isocyanates as a key intermediates, ${ }^{9}$ as well as ${ }^{11} \mathrm{C}$ carboxylic acids via metal-catalyzed aryl boronation reactions. ${ }^{10-11}$

Despite evident advantages of $\left[{ }^{11} \mathrm{C}\right] \mathrm{CO}_{2}$-fixation for radiotracer production, the radiochemistry has been generally restricted to semi-manual vial-based methods. Automation of this methodology would be highly desirable, not only from a user's perspective, as it would simplify the radiosynthesis process and reduce exposure to radioactivity, but also to improve its reproducibility and compliance of routine radiopharmaceutical production under current good manufacturing practices (cGMP). The aim of this study was two-fold: 1 ) to develop a simple and easily automated $\left[{ }^{11} \mathrm{C}^{1} \mathrm{CO}_{2^{-}}\right.$ fixation platform; and 2) to carry out proof-of-concept radiosyntheses of ${ }^{11} \mathrm{C}$-carbonyl labelled compounds with diverse scaffolds.

The traditional vial-based procedure was abandoned and we sought to take advantage of the captive solvent or "in-loop" technologies, that have been established for Grignard reactions ${ }^{12-15}$, or ${ }^{11} \mathrm{C}$-methylation, ${ }^{16-17}$ specifically, ease of automation, reliability, efficiency (minimal radioactive loss to the surrounding atmosphere, needles, septa, or to transfer from vessels), and in particular, its high surface-to-volume ratio, and should be ideally suited for $\left[{ }^{11} \mathrm{C}\right] \mathrm{CO}_{2}$-fixation radiochemistry. We selected model ${ }^{11} \mathrm{C}$-carbonyl labelled carbamates as well as symmetrical and unsymmetrical ureas based on their widespread use in radiotracer design and our clinical research interests for the proof-ofconcept radiolabelling by "in loop $\left[{ }^{11} \mathrm{C}_{\mathrm{CO}_{2}}\right.$-fixation" (Table 1 and Scheme 1). The radiotracers that were isolated in this study include, two new and structurally similar ${ }^{11} \mathrm{C}$ isotopologues of a fatty acid amide hydrolase (FAAH) inhibitor, $\left[{ }^{11} \mathrm{C}\right] \mathrm{JNJ} 1661010\left(\left[{ }^{11} \mathrm{C}\right] \mathbf{5}\right)$ and $\left[{ }^{11} \mathrm{C}\right] 7$, as well as the monoamine oxidase B (MAO-B) radiopharmaceutical, $\left[{ }^{11} \mathrm{C}\right] \mathrm{SL} 25.1188\left(\left[{ }^{11} \mathrm{C}\right] 2\right) .{ }^{18-20}$

\section{Results and Discussion}

The "in-loop" $\left[{ }^{11} \mathrm{C}_{\mathrm{CO}_{2}}\right.$-fixation apparatus is designed as a standalone system, where crude ${ }^{11} \mathrm{C}$-carbonylated products are generated for subsequent purification by chromatography. 
The method described herein consists of trapping and reacting $\left[{ }^{11} \mathrm{C}^{\mathrm{C}} \mathrm{CO}_{2}\right.$ directly in a stainless steel loop (as commonly used for sample injection in HPLC). The system is divided into two main parts: 1) the gas-phase entrapment and purification of in-target produced $\left[{ }^{11} \mathrm{C}_{\mathrm{CO}_{2}}\right.$; and 2) the "in-loop" reactor system, where $\left[{ }^{11} \mathrm{C}_{\mathrm{CO}_{2}}\right.$ is fixated and reacted to furnish the final ${ }^{11} \mathrm{C}$-carbonyl labelled product (Figure 1). For easy adoption of this method into a standard hot cell, we integrated the "in loop" system to a commercial radiosynthesis module (GE TracerLab $\mathrm{FX}_{\mathrm{FN}}$ ) to carry out automated HPLC purification and formulation of the labelled compounds.

Our initial focus was to optimize conditions for the "in-loop" $\left[{ }^{11} \mathrm{C}\right] \mathrm{CO}_{2}$-fixation reaction. The synthesis of $\left[{ }^{11} \mathrm{C}\right]$ methyl- $N$-benzylcarbamate $\left(\left[{ }^{11} \mathrm{C}\right] \mathbf{1 1}\right)$ was selected as a model reaction (Table 1). The experiments were carried out by bubbling $\left[{ }^{11} \mathrm{C}_{\mathrm{CO}}\right.$ in a stream of $\mathrm{N}_{2}(20$ $\mathrm{mL} / \mathrm{min})$ into the reactor loop with benzylamine $(4.6 \mu \mathrm{mol})$ and the $\mathrm{CO}_{2}$ fixating base, BEMP $(2.5 \mu \mathrm{L}, 8.6 \mu \mathrm{mol})$, dissolved in DMF, which was pre-loaded in section A of the reactor loop (Figure 1). The radiochemical yields (RCY) shown in Table 1 is non-isolated and determined by radio-HPLC. Initially, the intermediate $\left[{ }^{11} \mathrm{C}\right]$ carbamate ion $\left(\left[{ }^{11} \mathrm{C}\right] 9\right)$ was treated with methyl iodide (Table 1, Route 2 ) and to our delight, the desired ${ }^{11} \mathrm{C}$-labelled carbamate product was obtained in nearly quantitative yield (Table 1, entry 1). Next, we set to explore the $\left[{ }^{11} \mathrm{C}\right]$ isocyanide formation $\left(\left[{ }^{11} \mathrm{C}\right] \mathbf{1 0}\right.$, Table 1 , Route 1$)$. The $\left[{ }^{11} \mathrm{C}\right] \mathbf{1 1}$ formation was studied using different amounts of benzylamine $(0.15-4.6 \mu \mathrm{mol})$, with $\mathrm{POCl}_{3}(0.2 \%$ $\mathrm{v} / \mathrm{v}$ in $\mathrm{MeCN}$ ) as the dehydrating reagent, and the reaction mixture was quenched with an excess of methanol (50\% in DMF) pre-loaded in section B of the reactor loop (Figure 1). As anticipated, the reaction was strongly dependent on the amount of benzylamine $(\mathbf{8})$, as larger amounts of $\mathbf{8}$ led to formation of the undesirable symmetrical product, $\left[{ }^{11} \mathrm{C}\right]$ dibenzylurea $\left(\left[{ }^{11} \mathrm{C}\right] \mathbf{1 2}\right)$. For example, using $4.6 \mu \mathrm{mol}$ of $\mathbf{8}$, only $16 \%$ of $\left[{ }^{11} \mathrm{C}\right] \mathbf{1 1}$ was obtained with $\left[{ }^{11} \mathrm{C}\right] \mathbf{1 2}$ as the main ${ }^{11} \mathrm{C}$-labelled product (Table 1, entry 2 ). However, by reducing the amount of 8 to $0.3 \mu \mathrm{mol}$, a high and reproducible non-isolated RCY of $83 \pm 2 \%(\mathrm{n}=3)$ was obtained. Further reduction of $\mathbf{8}$ by 1 -fold resulted in a reduced yield (Table 1, entry 6).

One potential concern with ${ }^{11} \mathrm{C}$-reactions via captive solvent methods is the general dependency on solvents with high viscosity or boiling points, for example, DMF and DMSO. MeCN is the most common solvent in $\left[{ }^{11} \mathrm{C}_{\mathrm{CO}_{2}}\right.$-fixation radiochemistry. ${ }^{21-25}$ Our "in-loop" reactions demonstrated excellent compatibility with $\mathrm{MeCN}$ as a solvent in the reaction to prepare $\left[{ }^{11} \mathrm{C}\right] \mathbf{1 1}$, which resulted in excellent non-isolated RCY (91\%, Table 1, entry 7). Quantitative trapping efficiency was achieved for all examined solvents (MeCN, DMSO and DMF). However, a large variation in selectivity to the desired product was observed under these conditions (Table 1, entries 6-8). Despite superior yield obtained with MeCN, DMF was selected as the optimal solvent for the subsequent reactions, due to evaporation of $\mathrm{MeCN}$ that occurred while degassing with helium during our solution preparation. It is noteworthy that this degassing step was crucial in our hands for isolating ${ }^{11} \mathrm{C}$-labelled compounds with high molar radioactivity. Finally, in a last attempt to further increase the yield, BEMP was replaced with another commonly used fixating base, DBU. High trapping efficiency of $\left[{ }^{11} \mathrm{C}\right] \mathrm{CO}_{2}$ was obtained with $\mathrm{DBU}(>99 \%)$; however, the overall yield to the desired ${ }^{11} \mathrm{C}$-labelled product was reduced. In summary, our model reaction showed that ideal "in-loop" ${ }^{11} \mathrm{C}$-labelling conditions were achieved with BEMP $(8.6 \mu \mathrm{mol})$, 
benzylamine $(0.3 \mu \mathrm{mol})$ dissolved in DMF $(40 \mu \mathrm{L})$, followed by elution with $0.2 \% \mathrm{v} / \mathrm{v}$ $\mathrm{POCl}_{3}$ in $\mathrm{MeCN}(100 \mu \mathrm{L})$ and finally quenching with an excess of $50 \% \mathrm{v} / \mathrm{v}$ methanol in $\operatorname{DMF}(50 \mu \mathrm{L})$.

To further exemplify the utility of this newly developed method, using the established conditions for the "in-loop" $\left[{ }^{11} \mathrm{C}_{\mathrm{CO}_{2}}\right.$-fixation reaction (Table 1, entry 5), we set out to prepare three radiotracers (vide supra), namely $\left[{ }^{11} \mathrm{C}\right] \mathrm{SL} 25.1188\left(\left[{ }^{11} \mathrm{C}\right] 2\right),\left[{ }^{11} \mathrm{C}\right] \mathrm{JNJ} 1661010$ $\left(\left[{ }^{11} \mathrm{C}\right] 5\right.$ ), and $\left[{ }^{11} \mathrm{C}\right] 7$ (Scheme 1). The radiotracers were synthesized using both the standard vial-based method and our novel "in-loop" method (Table 2). In all cases, the "in-loop" methodology attained higher non-isolated RCYs compared with conventional reactions in a vial. For example, $\left[{ }^{11} \mathrm{C}\right] \mathrm{SL} 2511.88\left(\left[{ }^{11} \mathrm{C}\right] 2\right)$, was obtained in a two-fold higher non-isolated RCY using the "in-loop" methodology (Table 2, entry 1). It is important to note that our previous synthesis of $\left[{ }^{11} \mathrm{C}\right] 2$ resulted in comparable RCYs (60-70\%) when using a vial and $\mathrm{MeCN}$ as the solvent. ${ }^{15}$ However, the experimental conditions (including the solvent) for both methods were kept constant, to facilitate a direct comparison. Moreover, a staggering 15-fold improvement in non-isolated RCY was obtained for both FAAH inhibitor radioligands, $\left[{ }^{11} \mathrm{C}\right] \mathrm{JNJ} 1661010\left(\left[{ }^{11} \mathrm{C}\right] \mathbf{5}\right)$ and $\left[{ }^{11} \mathrm{C}\right] 7$, using the "in-loop" method (Table 2, entries 2 and 3$)$. It is noteworthy that higher amounts of the sparingly reactive primary amines ( 3 and 6, $55 \mu \mathrm{mol}$ and $75 \mu \mathrm{mol}$, respectively) were necessary to reach the high RCYs (Table 2, entries 2 and 3), indicating that the $\left[{ }^{11} \mathrm{C}\right]$ carbamate ion formation is promoted by higher amine concentration. The difference in RCYs between the two methods could be explained by the high surface-to-volume ratio inside the loop. Consequently, the "in-loop" method generates an ideal environment for efficient $\left[{ }^{11} \mathrm{C}_{\mathrm{CO}_{2}}\right.$ trapping and promotes the formation of the $\left[{ }^{11} \mathrm{C}\right]$ carbamate ion.

Carbon-11 labelled PET radiopharmaceuticals for in-vivo human studies are typically produced in GBq quantities. Therefore, to establish the utility of the current method, all three compounds were prepared on a large scale, starting from $110 \mathrm{GBq}(3 \mathrm{Ci})$ of $\left[{ }^{11} \mathrm{C}\right] \mathrm{CO}_{2}$. Compounds were isolated using semi-preparative HPLC followed by solid-phase extraction (SPE) to generate the final formulated product (for HPLC traces of $\left[{ }^{11} \mathrm{C}\right] \mathbf{2},\left[{ }^{11} \mathrm{C}\right] \mathbf{5}$ and $\left[{ }^{11} \mathrm{C}\right] 7$ see Figures $2-4$, respectively).

Table 2 shows that all compounds were produced in high RCP (>99\%) and molar radioactivities (80-134 GBq/ $\mu \mathrm{mol}(2162-3621 \mathrm{mCi} / \mu \mathrm{mol})$ ). Carbon-11 labelled 7 was isolated and formulated in sufficient quantities for in-vivo PET imaging studies (3.8 GBq; $103 \mathrm{mCi} ; 18 \%$ decay-corrected RCY, relative to starting $\left.\left[{ }^{11} \mathrm{C}\right] \mathrm{CO}_{2}\right)$. Compounds $\left[{ }^{11} \mathrm{C}\right] 2$ and $\left[{ }^{11} \mathrm{C}\right] 5$ were obtained in very high ( $\left.>50 \%\right)$ isolated RCYs, with 10.2 and $14.3 \mathrm{GBq}$ (276 and $387 \mathrm{mCi}$ ), respectively, ready for injection. PET imaging studies with all of these radiotracers are underway in our laboratories, and we are presently designing a fullyautomated version of the "in-loop" apparatus for cGMP radiopharmaceutical production. We anticipate that the simplicity of this "in-loop" methodology will facilitate widespread use and will provide comparable radiochemical yields and specific radioactivities to our previously developed ${ }^{11} \mathrm{C}$-urea- and carbamate-based radiotracers. ${ }^{21-23}$ Our future work will focus on ${ }^{11} \mathrm{C}$-carboxylation and amidation as innovative methodologies to achieve these reactions in radiopharmaceutical production are unveiled. 


\section{Conclusion}

We describe herein the development and design of a novel "in-loop" $\left[{ }^{11} \mathrm{C}\right] \mathrm{CO}_{2}$-fixation apparatus, which offers an efficient method for the production of a wide range of ${ }^{11} \mathrm{C}$ carbonylated radiotracers including ${ }^{11} \mathrm{C}$-oxazolidinones, ${ }^{11} \mathrm{C}$-ureas, and ${ }^{11} \mathrm{C}$-carbamates. The "in-loop" methodology was applied in the preparation of three ${ }^{11} \mathrm{C}$-carbonyl labelled PET radiotracers $\left(\left[{ }^{11} \mathrm{C}\right] 2,\left[{ }^{11} \mathrm{C}\right] 5,\left[{ }^{11} \mathrm{C}\right] 7\right)$ in high isolated yields $(>3.5 \mathrm{GBq})$ and radiochemical purity (>99\%). The molar radioactivity of all 3 compounds were above 80 $\mathrm{GBq} / \mu \mathrm{mol}$ ( $22162 \mathrm{Ci} / \mathrm{mmol}$ ) at the end-of-synthesis. Given its simplicity, we anticipate the current "in-loop" $\left[{ }^{11} \mathrm{C}_{\mathrm{CO}_{2}}\right.$ fixation methodology to be widely implemented in the development and routine production of PET radiopharmaceuticals.

\section{Experimental section}

\section{Materials and general methods}

All reagents and solvents were obtained from commercially available sources and used without further purification, unless specified otherwise. Anhydrous grade $\mathrm{MeCN}, \mathrm{MeOH}$ and DMF was purchased from Acros organics (USA); BEMP, DBU, aniline (3), benzylamine, methyl iodide, 1,2-benzisoxazol-3-amine (6), 3-phenyl-5-piperazino-1,2,4thiadiazole (4), JNJ-1661010 (5) as well as phosphorus(V) oxychloride $\left(\mathrm{POCl}_{3}\right)$ were all obtained from Aldrich (USA). A Tracerlab $\mathrm{FX}_{\mathrm{FN}}$ radiofluorination module (GE, Sweden) installed with a C18 semi-preparative HPLC column (ACE 5, C18-HL, $250 \times 10 \mathrm{~mm}$, Waters) was used for automated purification of the radiolabelled compounds. A HLB C18 light (30 mg, Waters) cartridge was used for SPE. An analytical HPLC system included a high-pressure gradient pump (Shimadzu LC-10AD pump), variable wavelength UV-detector (Shimadzu SPD-10AV), and a radioactivity detector. The system was controlled by Clarity ${ }^{\mathrm{TM}}$ 6.1 chromatography software. The radiochemical purity (RCP) of the isolated products was determined by reverse phase HPLC. Analysis was monitored using $254 \mathrm{~nm}$ as the detection wavelength. Identification of all radioactive products was confirmed by co-elution with the corresponding non-radioactive compound. The specific radioactivity (SA) was determined by HPLC.

\section{Prototype design}

A schematic of the $\left[{ }^{11} \mathrm{C}\right] \mathrm{CO}_{2}$ "in-loop" synthesizer is shown in Figure 1. All components were purchased from commercial sources. The operation of the module was controlled remotely via electrical switches from outside the hot cell. All reagents and solvents were conveniently stored in loops and transferred using controlled $\mathrm{N}_{2}$ gas flow (2 Bar) generated by a standard mass-flow controller (MFC, 0-2000 mL/min, OMEGA). The radioactive entrapment and release were monitored using scintillation detectors (Caroll \& Ramsey). $\left[{ }^{11} \mathrm{C}\right] \mathrm{CO}_{2}$ was trapped from the target using a stainless steel coil $\left(0.5-\mathrm{m}, 1 / 16^{\prime \prime}\right.$ o.d., $0.04{ }^{\prime \prime}$ i.d.) immersed into a vertically driven (air-pressure) Dewar vessel filled with nitrogen. Two 3-port, two-way valves (V1 and V2, P/N 009-0933-900, Parker) were used to direct $\mathrm{N}_{2}$ flow or target gas flow onto the liquid nitrogen trap. An 8-port, two-way HPLC injection valve (V3, P/N 170-0160H, Vici) was equipped with a reagent loop (1 mL (2-m), Tefzel ${ }^{\mathrm{TM}}, 1 / 16^{\prime \prime}$ o.d., 0.03 " i.d.) as well as a reactor loop (3.5 mL (7-m), stainless-steel, 1/16" o.d., 0.03" 
i.d.), which was applied as reaction vessel. Importantly, the reactor loop is dividable into two different sections: section A (1 mL (2-m)) and section B (2.5 mL (5-m)). Two unionconnectors (U1 and U2, P/N ZU1M, Valco) were used to combine the sections. This dualloop system makes it possible to pre-load two solutions at the same time. A sodium hydroxide-coated silica trap (Ascarite II, 20-30 mesh) was connected to the waste port of the HPLC valve and placed in a well counter to measure unreacted $\left[{ }^{11} \mathrm{C}\right] \mathrm{CO}_{2}$.

\section{Model reaction for the "in-loop" $\left[{ }^{11} \mathrm{C}\right] \mathrm{CO}_{2}$-fixation}

(a) Set-up-A schematic of the reactor loop is displayed in Figure 5. Prior to the start-ofsynthesis with the injection valve in position $A$ and by disconnecting the finger tight luer adaptors (Figure 5, U1, P-655 and P-660, Idex Health \& Science), a solution of alkylating $\left(10 \mu \mathrm{L}\right.$, methyl iodide) or dehydrating $\left(0.2 \mu \mathrm{L}, \mathrm{POCl}_{3}\right)$ agent in $\mathrm{MeCN}(100 \mu \mathrm{L})$ were loaded into the reagent loop using a $1 \mathrm{~mL}$ syringe. Furthermore, to the same loop, additional amount of MeCN $(800 \mu \mathrm{L})$ was added. A solution of appropriate amine, BEMP $(2.5 \mu \mathrm{L})$ in dimethylformamide ( $40 \mu \mathrm{L}, \mathrm{DMF}$ ), was loaded onto the reactor loop (Figure 5, section A). If "Route 1" (Table 1, scheme) are to be used, a solution of methanol $(25 \mu \mathrm{L})$ dissolved in DMF $(25 \mu \mathrm{L})$ was also loaded onto the reactor loop (Figure 5, section B). To enable reagent injection to the different sections of the reactor loop, the inlet nut on union-connectors (Figure 5, U2 and U3) were replaced by a needle injection port (\#VISF-2, Valco). It is important to note that prior to use, all solutions were de-gassed with helium flow for $15 \mathrm{~min}$ and kept over $4 \AA$ molecular sieves to minimize atmospheric $\mathrm{CO}_{2}$.

(b) Trapping and reaction-No-carrier-added $\left[{ }^{11} \mathrm{C}\right] \mathrm{CO}_{2}$ was prepared using a PET trace cyclotron (GE medical system, Sweden) via irradiation of a nitrogen target using $16.4 \mathrm{MeV}$ protons. After 1-min irradiation at $50 \mu \mathrm{A}$, typically $5 \mathrm{GBq}(140 \mathrm{mCi})$ of $\left[{ }^{11} \mathrm{C}\right] \mathrm{CO}_{2}$ was obtained at end-of-bombardment (EOB). The $\left[{ }^{11} \mathrm{C}_{\mathrm{CO}_{2}}\right.$ was transferred from the target chamber by the target gas $\left(1 \% \mathrm{O}_{2}\right.$ in $\left.\mathrm{N}_{2}\right)$ and concentrated in the liquid nitrogen trap of the $\left[{ }^{11} \mathrm{C}_{\mathrm{CO}_{2}}\right.$-fixation apparatus (Figure 1). The stainless-steel tube was removed from the liquid nitrogen by an air-pressure driven lift, whereby the $\left[{ }^{11} \mathrm{C}\right] \mathrm{CO}_{2}$ was passed through the coated reaction loop (Figure 5, Step 1) in a controlled stream of $\mathrm{N}_{2}(20 \mathrm{~mL} / \mathrm{min})$. When radioactivity peaked in the reaction loop, as measured by the proximal radiation detector (typically within $2 \mathrm{~min}$ ), the flow of $\mathrm{N}_{2}$ was stopped and the reaction was allowed to proceed for an additional $2 \mathrm{~min}$. Following this reaction, the position of the injection valve was switched to position $B$ (Figure 5, Step 2) and the content of the reactor loop was eluted out with a second reagent (alkylating or dehydration reagent in $\mathrm{MeCN}$ ) by a stream of nitrogen ( $80 \mathrm{~mL} / \mathrm{min}$ ) into an empty receiving vial (5 mL, glass v-vial, Alltech). Moreover, the preloaded $\mathrm{MeCN}$ was immediately flushed through the reactor loop to maximize recovery. The crude radioactive product was dissolved in $3.5 \mathrm{~mL}$ of water and injected onto a $\mathrm{GE}$ TracerLab $\mathrm{FX}_{\mathrm{FN}}$ radiofluorination module for HPLC purification and formulation.

(c) Clean-up-The $\left[{ }^{11} \mathrm{C}\right] \mathrm{CO}_{2}$-fixation module was easily cleaned by passing $5 \mathrm{~mL}$ volumes of water, $\mathrm{MeCN}$ and acetone through both loops (reactor and reagent loop) with the injection valve in position $B$ (Figure 5), and flushed using $\mathrm{N}_{2}$ gas $(500 \mathrm{~mL} / \mathrm{min})$ for $15 \mathrm{~min}$. 


\section{Precursor and non-radioactive standard synthesis}

Precursors and the non-radioactive standards for the $\left[{ }^{11} \mathrm{C}_{\mathrm{CO}_{2}}\right.$-fixation reactions were either synthesized in-house (1, 2 and $\mathbf{7})$ or were obtained from commercially available sources (3, 4, 5 and 6). Compounds included in this study are depicted in Scheme 1. SL25.1188 reference standard (2) and the corresponding precursor compound (1) were synthesized in 5and 6-steps, respectively, starting from 4-(benzyloxy)-2-fluorobenzonitrile via reduction, alkylation, and hydrolysis (Scheme 2). ${ }^{18,26}$ Moreover, the non-radioactive standard 7 was synthesized in two-steps starting from 6 (Scheme 3).

\section{Synthesis of SL25.1188 reference (2) and precursor (1) compounds}

6-(Benzyloxy)benzo[d]isoxazol-3-amine (13)—Acetone oxime (20 mmol) was added to a solution of $1 \mathrm{M}$ potassium tert-butoxide in THF $(20 \mathrm{~mL}, 20 \mathrm{mmol})$. The solution was kept at room temperature (r.t.) for 20 min, after which a solution of 4-(benzyloxy)-2fluorobenzonitrile $(18.5 \mathrm{mmol})$ in THF $(15 \mathrm{~mL})$ was slowly added using an addition funnel. After stirring for $3 \mathrm{~h}$ at r.t., the mixture was heated at $60^{\circ} \mathrm{C}$ overnight. A dark brown solution was obtained. The reaction mixture was quenched with water $(10 \mathrm{~mL})$ and partitioned between saturated $\mathrm{NaHCO}_{3}$ solution $(5 \mathrm{~mL})$ and ethyl acetate $(75 \mathrm{~mL})$. The organic layers were separated and washed with water $(3 \times 30 \mathrm{~mL})$. A brown solid was obtained upon solvent removal using a rotary evaporator. The solid was then treated with a mixture of EtOH $(40 \mathrm{~mL}), \mathrm{H}_{2} \mathrm{O}(26 \mathrm{~mL})$ and $\mathrm{HCl}(12 \mathrm{~N}, 14 \mathrm{~mL})$ at reflux for $2 \mathrm{~h}$. After cooling, the reaction mixture was basified with solid sodium carbonate and $\mathrm{NaOH}(1 \mathrm{~N}, 15 \mathrm{~mL})$, followed by extraction with ethyl acetate $(2 \times 100 \mathrm{~mL})$. The combined organic layers were washed with brine $(50 \mathrm{~mL})$, dried over $\mathrm{MgSO}_{4}$, and the solvent was removed under reduced pressure. The residue was purified using chromatography on silica gel by eluting with a 1:3 mixture of ethyl acetate and hexane. The product was obtained as a white solid. Yield: 62\%; ${ }^{1} \mathrm{H}$ NMR $\left(300 \mathrm{MHz}, \mathrm{CDCl}_{3}\right) \delta 7.31-7.48(\mathrm{~m}, 6 \mathrm{H}), 6.90-6.97(\mathrm{~m}, 2 \mathrm{H}), 5.12(\mathrm{~s}, 2 \mathrm{H}), 4.30$ $(\mathrm{s}, 2 \mathrm{H})$.

Ethyl 6-(benzyloxy)benzo[d]isoxazol-3-ylcarbamate (14)-Ethyl chloroformate (1.2 mmol) was added dropwise to a solution of $13(1 \mathrm{mmol})$ and pyridine $(2 \mathrm{mmol})$ maintained at $0{ }^{\circ} \mathrm{C}$. The mixture was stirred at $0{ }^{\circ} \mathrm{C}$ for $4 \mathrm{~h}$, poured into water and extracted with ethyl acetate $(2 \times 20 \mathrm{~mL})$. The combined organic layers were washed with brine $(20 \mathrm{~mL})$, dried over $\mathrm{MgSO}_{4}$, and the solvent was evaporated in vacuo. The residue was purified by chromatography on silica gel by eluting with a 1:3 mixture of ethyl acetate and hexane. The product was obtained as a white solid. Yield: $93 \% ;{ }^{1} \mathrm{H} \mathrm{NMR}\left(300 \mathrm{MHz}, \mathrm{CDCl}_{3}\right) \delta 8.08(\mathrm{~d}, J$ $=9.6 \mathrm{~Hz}, 1 \mathrm{H}), 7.86(\mathrm{~s}, 1 \mathrm{H}), 7.30-7.49(\mathrm{~m}, 5 \mathrm{H}), 6.95-7.03(\mathrm{~m}, 2 \mathrm{H}), 5.13(\mathrm{~s}, 2 \mathrm{H}), 4.32(\mathrm{q}, J$ $=7.1 \mathrm{~Hz}, 2 \mathrm{H}), 1.36(\mathrm{t}, J=7.1 \mathrm{~Hz}, 3 \mathrm{H}) .{ }^{13} \mathrm{C} \mathrm{NMR}\left(75 \mathrm{MHz}, \mathrm{CDCl}_{3}\right) \delta 166.1,161.5,153.1$, 153.0, 135.9, 128.7, 128.3, 127.5, 125.2, 114.6, 108.9, 93.5, 70.5, 62.4, 14.4 .

(S)-3-(6-(Benzyloxy)benzo[d]isoxazol-3-yl)-5-(methoxymethyl)oxazolidin-2-one (15) - A solution of $14(0.9 \mathrm{mmol})$ in $1 \mathrm{~mL}$ of DMF was added to a solution of $(R)-4-$ (methoxymethyl)-1,3-dioxolan-2-one $(1.7 \mathrm{mmol})$ and potassium carbonate $(0.085 \mathrm{mmol})$ in $2 \mathrm{~mL}$ DMF at $140{ }^{\circ} \mathrm{C}$. The mixture was stirred at $140{ }^{\circ} \mathrm{C}$ for $2 \mathrm{~h}$. After cooling the solution was evaporated in vacuo. The residue was purified by chromatography on silica gel by eluting with a 1:3 mixture of ethyl acetate and hexane. The product was obtained as a white 
solid. Yield: 62\%; ${ }^{1} \mathrm{H}$ NMR (300 MHz, $\left.\mathrm{CDCl}_{3}\right) \delta 8.41(\mathrm{~d}, J=9.7 \mathrm{~Hz}, 1 \mathrm{H}), 7.30-7.49(\mathrm{~m}$, $5 \mathrm{H}), 6.95-7.02(\mathrm{~m}, 2 \mathrm{H}), 5.14(\mathrm{~s}, 2 \mathrm{H}), 4.85-4.96(\mathrm{~m}, 1 \mathrm{H}), 4.23(\mathrm{dd}, J=9.9,8.9 \mathrm{~Hz}, 1 \mathrm{H})$, $4.11(\mathrm{dd}, J=10.0,6.5 \mathrm{~Hz}, 1 \mathrm{H}), 3.69(\mathrm{qd}, J=10.8,4.1 \mathrm{~Hz}, 2 \mathrm{H}), 3.45(\mathrm{~s}, 3 \mathrm{H}) .{ }^{13} \mathrm{C}$ NMR $(75$ $\left.\mathrm{MHz}, \mathrm{CDCl}_{3}\right) \delta 166.4,161.5,153.8,152.9,135.9,128.7,128.3,127.5,126.5,114.5,108.2$, $93.4,73.8,72.4,70.5,59.6,46.6$.

(S)-3-(6-Hydroxybenzo[d]isoxazol-3-yl)-5-(methoxymethyl)oxazolidin-2-one (16)—A solution of $\mathbf{1 5}(8.47 \mathrm{mmol})$ and $\mathrm{Pd} / \mathrm{C}(500 \mathrm{mg})$ in $100 \mathrm{~mL}$ EtOH/THF (1:1) under hydrogen atmosphere was stirred at r.t. for $60 \mathrm{~min}$. Upon completion of the reaction, the mixture was filtered through Celite ${ }^{\circledR}$ and the filtrate was evaporated in vacuo. The residue was purified by chromatography on silica gel by eluting with a 1:2 mixture of ethyl acetate and hexane. The product was obtained as a white solid. Yield: $95 \%$; ${ }^{1} \mathrm{H}$ NMR $(300 \mathrm{MHz}$, DMSO) $\delta 10.46(\mathrm{~s}, 1 \mathrm{H}), 8.19(\mathrm{~d}, J=8.9 \mathrm{~Hz}, 1 \mathrm{H}), 6.89(\mathrm{~d}, J=2.0 \mathrm{~Hz}, 1 \mathrm{H}), 6.83(\mathrm{dd}, J=8.9$, $2.1 \mathrm{~Hz}, 1 \mathrm{H}), 4.88-5.06(\mathrm{~m}, 1 \mathrm{H}), 4.16(\mathrm{t}, J=9.3 \mathrm{~Hz}, 1 \mathrm{H}), 3.85(\mathrm{dd}, J=9.6,6.3 \mathrm{~Hz}, 1 \mathrm{H})$, $3.54-3.72(\mathrm{~m}, 2 \mathrm{H}) .{ }^{13} \mathrm{C}$ NMR (75 MHz, DMSO) $\delta 166.3,161.0,154.2,153.1,126.5$, $114.4,106.8,95.0,74.5,72.6,59.1,46.5$.

\section{(S)-5-(Methoxymethyl)-3-(6-(4,4,4-trifluorobutoxy)benzo[d]isoxazol-3-} yl)oxazolidin-2-one (SL25.1188, 2)-16 (7.6 mmol) was added to a solution of 1,1,1trifluorobutane $(10.5 \mathrm{mmol})$ and potassium carbonate $(15.2 \mathrm{mmol})$ in $28 \mathrm{~mL} \mathrm{MeCN}$. The mixture was heated to reflux for $2 \mathrm{~h}$. The mixture was than cooled, filtered and evaporated under reduced pressure. The residue was purified by chromatography on silica gel by eluting with a 1:3 mixture of ethyl acetate and hexane. The product was obtained as a white solid. Yield: 76\%. ${ }^{1} \mathrm{H}$ NMR $\left(300 \mathrm{MHz}, \mathrm{CDCl}_{3}\right) \delta 8.41(\mathrm{~d}, J=9.7 \mathrm{~Hz}, 1 \mathrm{H}), 6.82-6.95(\mathrm{~m}, 2 \mathrm{H})$, $4.84-5.00(\mathrm{~m}, 1 \mathrm{H}), 4.20-4.27(\mathrm{~m}, 1 \mathrm{H}), 4.03-4.17(\mathrm{~m}, 3 \mathrm{H}), 3.69(\mathrm{qd}, J=10.8,4.1 \mathrm{~Hz}$, $2 \mathrm{H}), 3.45(\mathrm{~s}, 3 \mathrm{H}), 2.25-2.45(\mathrm{~m}, 2 \mathrm{H}), 2.04-2.20(\mathrm{~m}, 2 \mathrm{H}) .{ }^{19} \mathrm{~F} \mathrm{NMR}\left(282 \mathrm{MHz}, \mathrm{CDCl}_{3}\right) \delta$ $-66.3(\mathrm{t}, J=10.8 \mathrm{~Hz})$.

\section{(S)-1-Methoxy-3-(6-(4,4,4-trifluorobutoxy)benzo[d]isoxazol-3-} ylamino)propan-2-ol (1)-To a solution of 2 (1.4 mmol) in EtOH (7 mL), aq. $\mathrm{NaOH}(1.3$ $\mathrm{N}, 5.4 \mathrm{~mL}, 7 \mathrm{mmol}$ ) was added. The mixture was stirred at r.t. overnight. The resulting solution was diluted with water $(50 \mathrm{~mL})$ and EtOAc $(50 \mathrm{~mL})$. The combined organic layers were washed with brine $(20 \mathrm{~mL})$, dried over $\mathrm{MgSO}_{4}$, and the solvent was evaporated in vacuo. The residue was purified by chromatography on silica gel by eluting with a 1:1 mixture of ethyl acetate and hexane. The product was obtained as a white solid. Yield: 90\%; ${ }^{1} \mathrm{H}$ NMR (300 MHz, DMSO) $\delta 7.73(\mathrm{~d}, J=8.7 \mathrm{~Hz}, 1 \mathrm{H}), 6.99(\mathrm{~d}, J=1.9 \mathrm{~Hz}, 1 \mathrm{H}), 6.78-$ $6.88(\mathrm{~m}, 2 \mathrm{H}), 4.96(\mathrm{~d}, J=5.2 \mathrm{~Hz}, 1 \mathrm{H}), 4.08(\mathrm{t}, J=6.2 \mathrm{~Hz}, 2 \mathrm{H}), 3.89$ (dq, $J=10.5,5.3 \mathrm{~Hz}$, $1 \mathrm{H}), 3.21-3.34(\mathrm{~m}, 5 \mathrm{H}), 3.04-3.16(\mathrm{~m}, 1 \mathrm{H}), 2.30-2.46(\mathrm{~m}, 2 \mathrm{H}), 1.86-2.01(\mathrm{~m}, 2 \mathrm{H}) .{ }^{13} \mathrm{C}$ NMR (75 MHz, DMSO) $\delta 164.1,161.1,158.7,128.1$ (q, $J=277.0 \mathrm{~Hz}), 122.5,112.4,110.1$, 94.0, 75.5, 67.8, 66.8, 58.8, 46.8, 29.9 (q, $J=30.0 \mathrm{~Hz}), 21.9$ (d, $J=3.0 \mathrm{~Hz}) .{ }^{19} \mathrm{~F}$ NMR $(282$ MHz, DMSO) $\delta-64.8(\mathrm{t}, J=11.6 \mathrm{~Hz})$.

\section{Synthesis of reference compound (7)}

$\mathrm{N}$-(benzo[d]isoxazol-3-yl)-4-(3-phenyl-1,2,4-thiadiazol-5-yl)piperazine-1carboxamide (7)—2,2,2-Trichloroethyl chloroformate (15mg, $72 \mu \mathrm{mol})$ was added to a 
solution of benzo[ $d$ ] isoxazol-3-amine $(6,8.4 \mathrm{mg}, 60 \mu \mathrm{mol})$ and pyridine $(5.7 \mathrm{mg}, 72 \mu \mathrm{mol})$ in THF $(0.6 \mathrm{~mL})$ maintained at $0{ }^{\circ} \mathrm{C}$. The mixture was kept at $0{ }^{\circ} \mathrm{C}$ for $1.5 \mathrm{~h}$ under stirring. The resulting solution was quenched with water and subsequently extracted with EtOAc $(3 \times$ $5 \mathrm{~mL}$ ). The combined organic layers were washed with brine $(20 \mathrm{~mL})$, dried over $\mathrm{MgSO}_{4}$, and the solvent was removed in vacuo to yield the crude intermediate product (17). Next, $\mathrm{N}$ ethyldiisopropylamine ( $4.2 \mathrm{mg}, 32 \mu \mathrm{mol})$ was added to a solution of $\mathbf{1 7}(8.0 \mathrm{mg}, 26 \mu \mathrm{mol})$ and 3-phenyl-5-(piperazin-1-yl)-1,2,4-thiadiazole (4, $8.5 \mathrm{mg}, 34 \mu \mathrm{mol})$ in DMSO (0.6 mL). The mixture was stirred at $70{ }^{\circ} \mathrm{C}$ for $2 \mathrm{~h}$, quenched with water and subsequently extracted with EtOAc $(2 \times 5 \mathrm{~mL})$. The combined organic layer was washed with brine and dried over anhydrous $\mathrm{MgSO}_{4}$ and concentrated in vacuo. The residue was purified by preparative TLC by eluting with a 10:1 mixture of dichloromethane and methanol. The product was obtained as a yellow solid. Yield: $32 \%$ over two steps; ${ }^{1} \mathrm{H}$ NMR $\left(300 \mathrm{MHz}, \mathrm{DMSO}-d_{6}\right) \delta 10.01$ (s, $1 \mathrm{H}), 8.14-8.09(\mathrm{~m}, 2 \mathrm{H}), 7.85(\mathrm{~d}, J=7.8 \mathrm{~Hz}, 1 \mathrm{H}), 7.65-7.55(\mathrm{~m}, 2 \mathrm{H}), 7.48-7.45(\mathrm{~m}, 3 \mathrm{H})$, $7.33-7.27(\mathrm{~m}, 1 \mathrm{H}), 3.72(\mathrm{~s}, 4 \mathrm{H}), 3.68(\mathrm{~s}, 4 \mathrm{H}) .{ }^{13} \mathrm{C}$ NMR (75 MHz, DMSO- $\left.d_{6}\right) \delta 185.2$, $169.5,163.4,155.8,154.3,133.3,130.7,130.5,129.1,128.0,125.1,123.3,117.3,110.2$, $48.8,43.7$.

\section{Acknowledgments}

We would like to thank the staff at the Radiochemistry Program, Massachusetts General Hospital and Harvard Medical School for their support. R.C. is supported by China Scholarship Council (201506250036). S.H.L. is a recipient of an NIH career development award (DA038000). N.V. thanks National Institute on Ageing of the NIH for funding this work (R01AG054473).

\section{References}

1. Miller PW, Long NJ, Vilar R, Gee AD. Angew Chem Int Ed. 2008; 47:8998.

2. Ametamey SM, Honer H, Schubiger PA. Chem Rev. 2008; 108:1501. [PubMed: 18426240]

3. Pike VW. Curr Med Chem. 2016; 23:1818. [PubMed: 27087244]

4. Dahl K, Halldin C, Schou M. Clin Transl Imaging. 2017; 5:257.

5. Rotstein BH, Liang SH, Placzek MS, Hooker JM, Gee AD, Dollé F, Wilson AA, Vasdev N. Chem Soc Rev. 2016; 45:4708. [PubMed: 27276357]

6. Rotstein BH, Liang SH, Holland JP, Collier TL, Hooker JM, Wilson AA, Vasdev N. Chem Comm. 2013; 49:5621. [PubMed: 23673726]

7. Hooker JM, Reibel A, Hill S, Schueller M, Fowler JS. Angew Chem Int Ed. 2009; 48:3482.

8. Wilson AA, Garcia A, Houle S, Vasdev N. Org Biomol Chem. 2010; 8:428. [PubMed: 20066280]

9. Wilson AA, Garcia A, Houle S, Sadovski O, Vasdev N. Chem Eur J. 2011; 17:259. [PubMed: 21207622]

10. Riss PJ, Lu S, Telu S, Aigbirhio FI, Pike VW. Angew Chem Int Ed. 2012; 51:2698.

11. Rotstein BH, Hooker JM, Woo J, Collier TL, Brady TJ, Liang SH, Vasdev N. ACS Med Chem Lett. 2014; 5:668. [PubMed: 24944741]

12. Davenport RJ, Pike VW, Dowsett K, Turton DR, Poole K. Appl Radiat Isot. 1997; 48:917. [PubMed: 9376826]

13. Davenport RJ, Dowsett K, Pike VW. Appl Radiat Isot. 1997; 48:1117.

14. Matarrese M, Sudati F, Soloviev D, Todde S, Turolla EA, Kienle MG, Fazio F. Appl Radiat Isot. 2002; 57:675. [PubMed: 12433041]

15. Zhang MR, Ogawa M, Yoshida Y, Suzuki K. Appl Radiat Isot. 2006; 64:216. [PubMed: 16194603]

16. Wilson AA, Garcia A, Jin L, Houle S. Nucl Med Biol. 2000; 27:529. [PubMed: 11056365]

17. Wilson AA, Garcia A, Houle S, Vasdev N. J Label Compd Radiopharm. 2009; 52:490. 
18. Saba W, Valette H, Peyronnea M, Bramoulle Y, Coulon C, Curet O, George P, Dolle F, Bottlaender M. Synapse. 2010; 64:61. [PubMed: 19728365]

19. Vasdev N, Sadovski O, Garcia A, Dollé F, Meyer JH, Houle S, Wilson AA. J Label Compd Radiopharm. 2011; 54:678.

20. Rusjan P, Wilson AA, Miler L, Fan I, Mizrahi R, Houle S, Vasdev N, Meyer JH. J Cereb Blood Flow Metab. 2014; 34:883. [PubMed: 24517979]

21. Hicks JW, Parkes J, Sadovski O, Tong J, Houle S, Vasdev N, Wilson AA. Nucl Med Biol. 2013; 40:740. [PubMed: 23731552]

22. Hicks JW, Wilson AA, Rubie EA, Woodgett JR, Houle S, Vasdev N. Bioorg Med Chem Lett. 2012; 22:2099. [PubMed: 22321216]

23. Wilson AA, Hicks JW, Sadovski O, Parkes J, Tong J, Houle S, Fowler C, Vasdev N. J Med Chem. 2013; 56:201. [PubMed: 23214511]

24. Dheere A, Yusuf N, Gee AD. Chem Comm. 2013; 49:8193. [PubMed: 23925577]

25. Mossine AV, Brooks AF, Jackson IM, Quesada CA, Sherman P, Cole EL, Donnelly DJ, Scott PJH, Shao X. Bioconjugate Chem. 2016; 27:1382.

26. Jegham S, Puech F, Burnier P. PCT Int Appl. 1996 WO9638444 A1. 


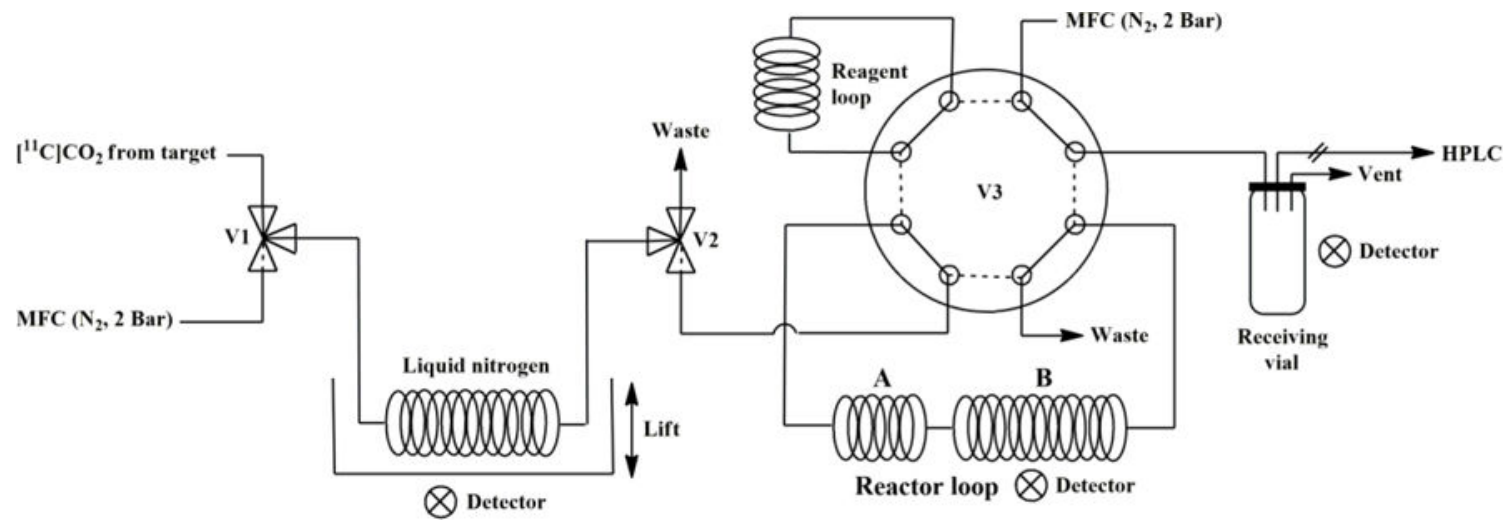

Figure 1.

Schematic drawing of the "in-loop" $\left[{ }^{11} \mathrm{C}\right] \mathrm{CO}_{2}$-fixation module. 
A.
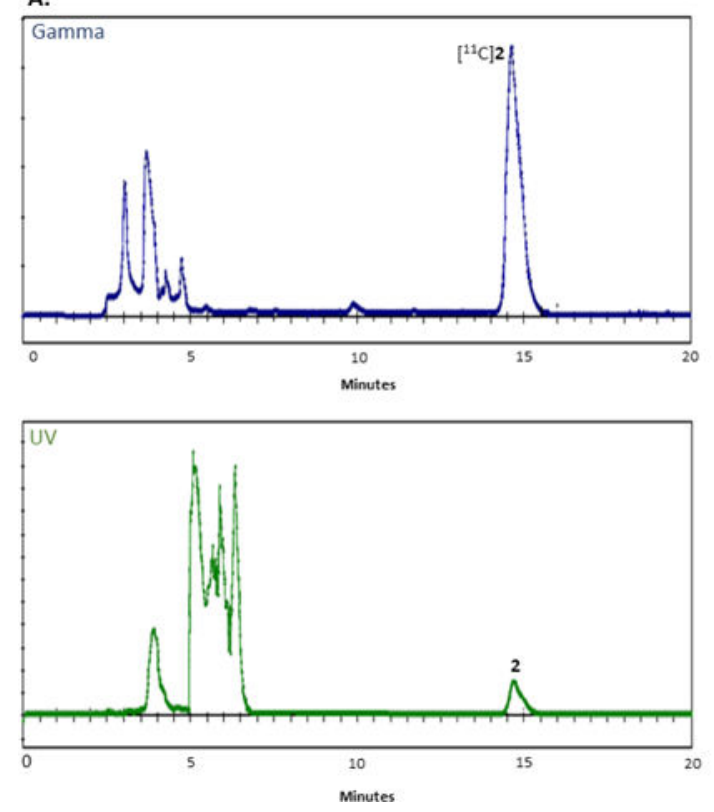

B.
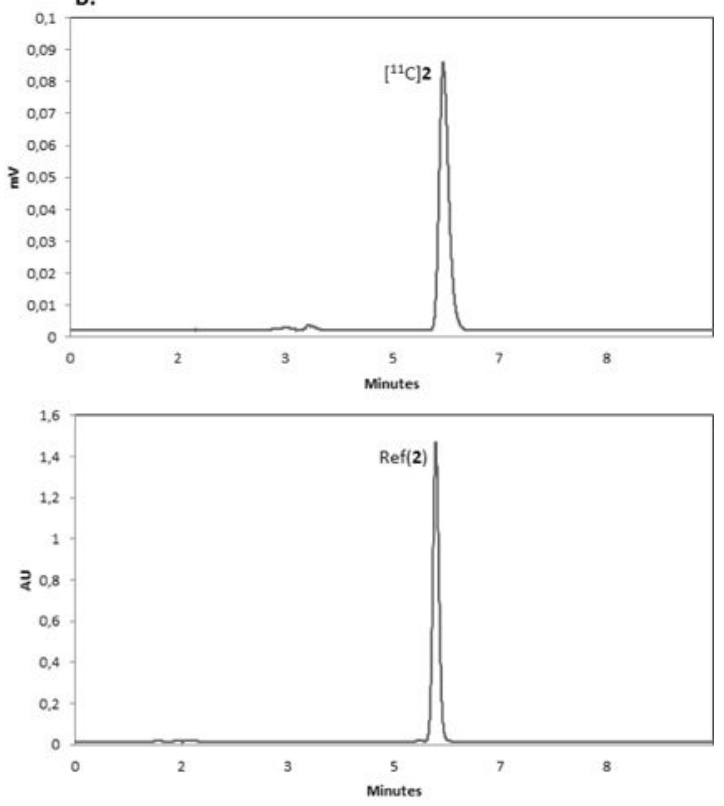

Figure 2.

A) Semi-preparative HPLC trace (55:45 $\mathrm{MeCN}$ : $10 \mathrm{mM} \mathrm{NH} \mathrm{mCO}_{2}$, at a flow rate $7 \mathrm{~mL} / \mathrm{min}$, ACE $5 \mathrm{C} 18,5 \mu \mathrm{m}, 10 \times 250 \mathrm{~mm}$ ) of a typical radiosynthesis of $\left[{ }^{11} \mathrm{C}\right] 2$, purified using a $\mathrm{GE}$ TracerLab FX $\mathrm{FN}_{\mathrm{F}}$ radiosynthesis module. Gamma $\left(t_{\mathrm{R}}=14.7\right.$ minutes; top $)$, and $\mathrm{UV}(\lambda=254$ $\mathrm{nm}$; bottom). Units on the y-axis are arbitrary. B) Analytical HPLC trace (50:50 $\mathrm{MeCN}: \mathrm{H}_{2} \mathrm{O}$, at a flow rate of $1 \mathrm{~mL} / \mathrm{min}$, XBridge $\mathrm{C}-18,3.5 \mu \mathrm{m}, 150 \times 4.6 \mathrm{~mm}$ ) of a typical analysis of $\left[{ }^{11} \mathrm{C}\right] 2$. Gamma $\left(t_{\mathrm{R}} \sim 5\right.$ minutes; top $)$, and $U V(\lambda=254 \mathrm{~nm}$; bottom $)$. Units on the $y$-axis are arbitrary. 

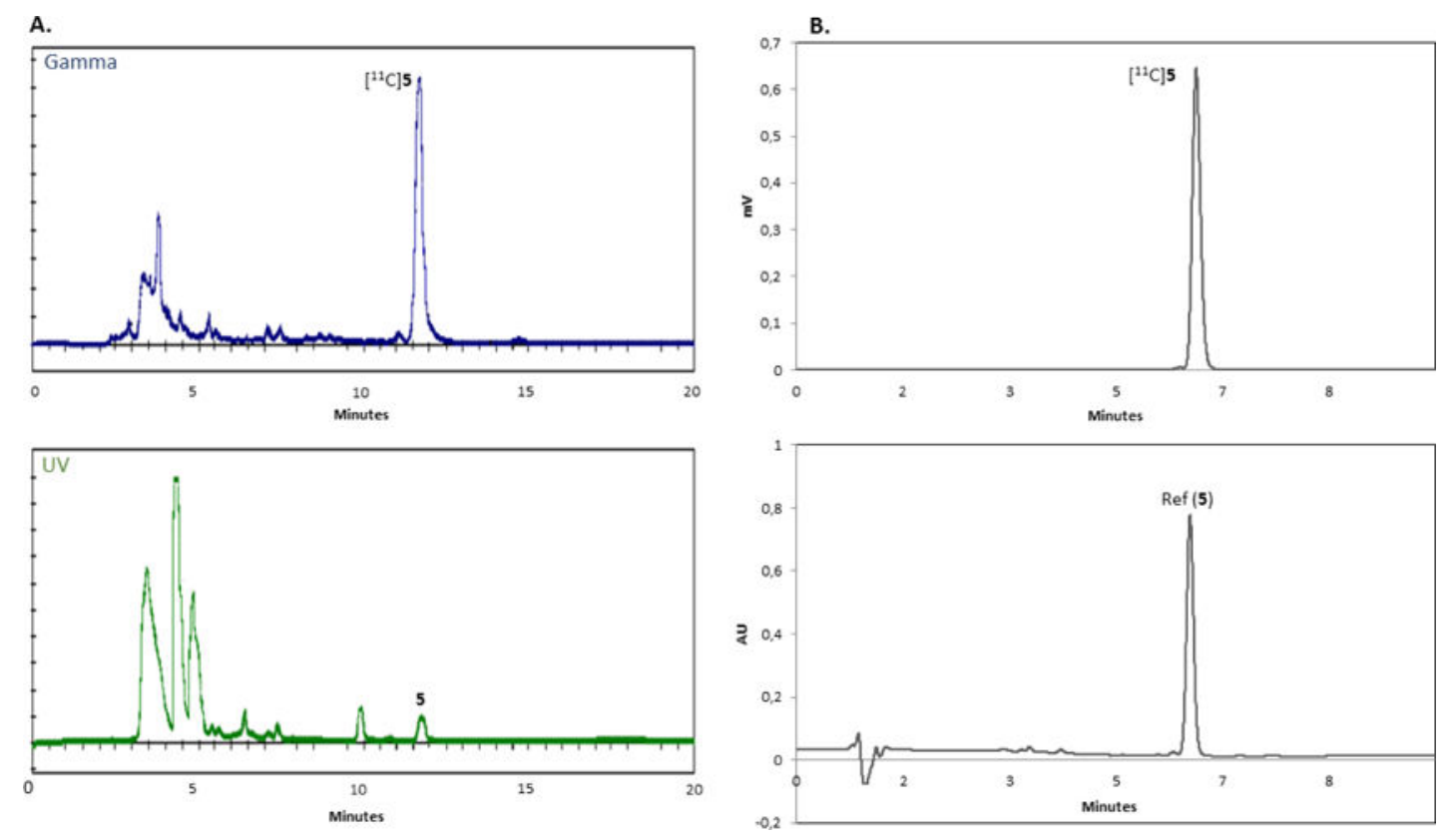

Figure 3.

A) Semi-preparative HPLC trace (55:45 MeCN: $10 \mathrm{mM} \mathrm{NH}_{4} \mathrm{CH}_{3} \mathrm{CO}_{2}$, at a flow rate of 5 $\mathrm{mL} / \mathrm{min}, \mathrm{ACE} 5-\mathrm{C} 18,5 \mu \mathrm{m}, 10 \times 250 \mathrm{~mm})$ of a typical radiosynthesis of $\left[{ }^{11} \mathrm{C}\right] \mathbf{5}$, purified using a GE TracerLab FX $\mathrm{FN}_{\mathrm{FN}}$ radiosynthesis module. Gamma ( $t_{\mathrm{R}}=11.8$ minutes; top), and $\mathrm{UV}(\lambda=254 \mathrm{~nm}$; bottom). Units on the y-axis are arbitrary. B) Analytical HPLC trace $\left(50: 50 \mathrm{MeCN}: \mathrm{H}_{2} \mathrm{O}\right.$, at a flow rate of $1.5 \mathrm{~mL} / \mathrm{min}$, XBridge $\left.\mathrm{C}-18,3.5 \mu \mathrm{m}, 150 \times 4.6 \mathrm{~mm}\right)$ of a typical analysis of $\left[{ }^{11} \mathrm{C}\right] 5$. Gamma $\left(t_{\mathrm{R}} \sim 6.5\right.$ minutes; top $)$, and $\mathrm{UV}(\lambda=254 \mathrm{~nm}$; bottom). Units on the y-axis are arbitrary. 
A.
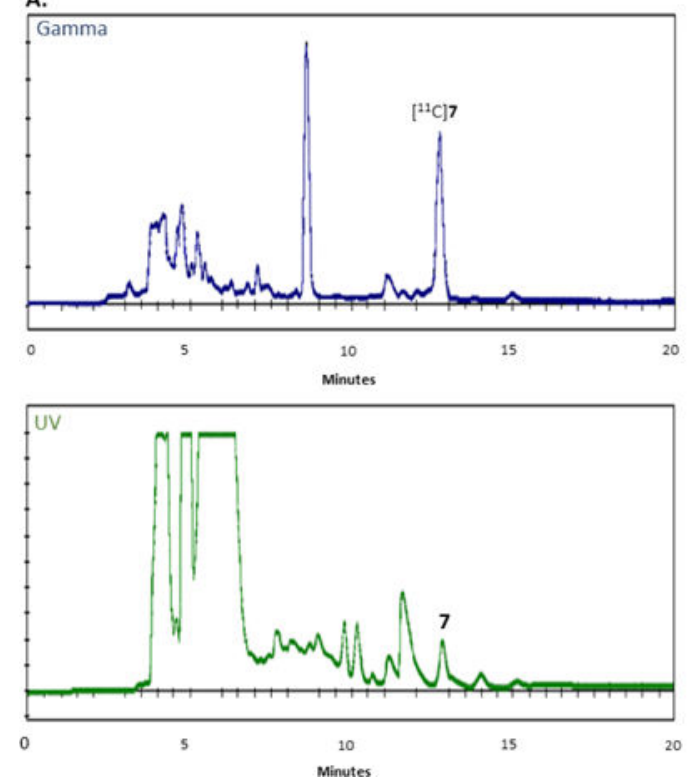

B.
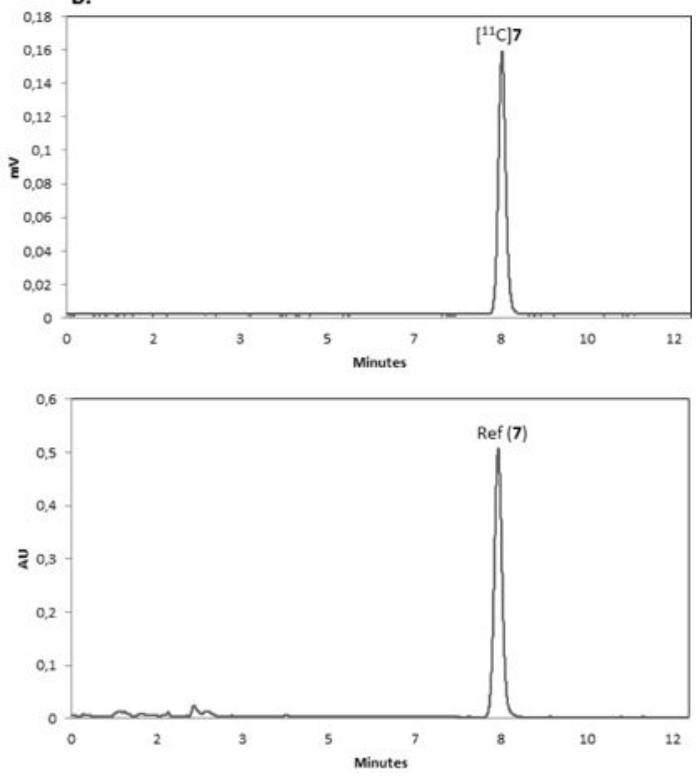

Figure 4.

A) Semi-preparative HPLC trace (55:45 MeCN: $10 \mathrm{mM} \mathrm{NH}_{4} \mathrm{CH}_{3} \mathrm{CO}_{2}$, at a flow rate $5 \mathrm{~mL} /$ min, ACE 5-C18, $5 \mu \mathrm{m}, 10 \times 250 \mathrm{~mm}$ ) of a typical radiosynthesis of $\left[{ }^{11} \mathrm{C}\right] 7$, purified using a GE TracerLab $\mathrm{FX}_{\mathrm{FN}}$ radiosynthesis module. Gamma $\left(t_{\mathrm{R}}=12.7\right.$ minutes; top), and UV ( $\lambda=$ $254 \mathrm{~nm}$; bottom). Units on the y-axis are arbitrary. B) Analytical HPLC trace (50:50 $\mathrm{MeCN}: \mathrm{H}_{2} \mathrm{O}$, at a flow rate of $1.5 \mathrm{~mL} / \mathrm{min}$, XBridge C-18, $3.5 \mu \mathrm{m}, 150 \times 4.6 \mathrm{~mm}$ ) of a typical analysis of $\left[{ }^{11} \mathrm{C}\right] 7$. Gamma $\left(t_{\mathrm{R}} \sim 8\right.$ minutes; top), and $\mathrm{UV}(\lambda=254 \mathrm{~nm}$; bottom). Units on the $y$-axis are arbitrary. 
Step 1: "In-loop" $\left[{ }^{11} \mathrm{C}\right] \mathrm{CO}_{2}$ fixation

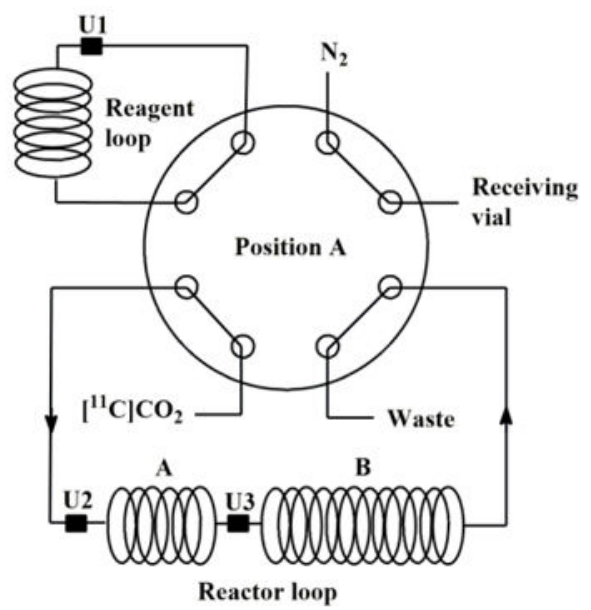

Step 2: Elution and "in-loop" reaction

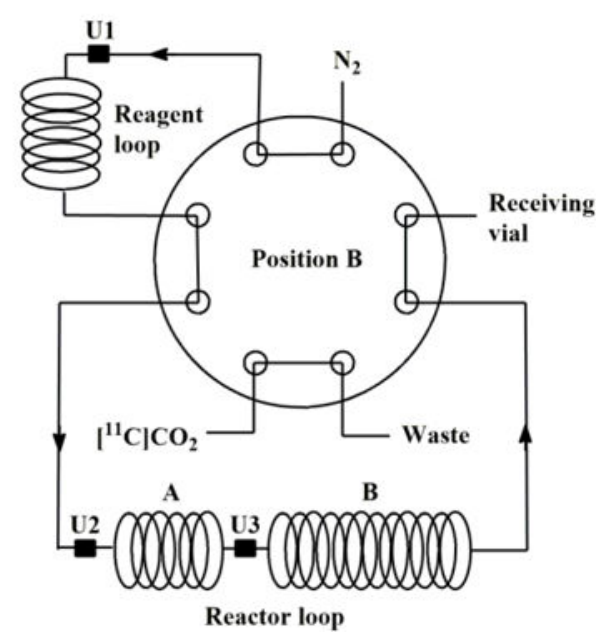

Figure 5.

General "in-loop" $\left[{ }^{11} \mathrm{C}\right] \mathrm{CO}_{2}$-fixation radiosynthesis procedure. Step 1: The "in-loop" $\left[{ }^{11} \mathrm{C}_{\mathrm{CO}_{2}}\right.$ fixation in a pre-loaded trapping-solution (BEMP, amine dissolved in DMF) to form the intermediate product, $\left[{ }^{11} \mathrm{C}\right]$ carbamate ion (reactor loop, section A). Step 2: Elution and "in-loop" reaction using a pre-loaded solution $\left(\mathrm{POCl}_{3}\right.$ or methyl iodide in reagent loop) in section A of the reactor loop, followed by a second in-loop reaction with a pre-loaded nucleophile (alcohol or amine) in section B of the reactor loop. 
A)<smiles>COC[C@H](O)CNc1noc2cc(OCCCC(F)(F)F)ccc12</smiles><smiles>COC[C@H]1CN(c2noc3cc(OCCCC(F)(F)F)ccc23)C(=O)O1</smiles>

$\left[{ }^{11} \mathrm{C}\right] 2, \mathrm{SL} 25.1188$

B)<smiles>Nc1ccccc1</smiles>

1. $\left[{ }^{11} \mathrm{C}\right] \mathrm{CO}_{2}$

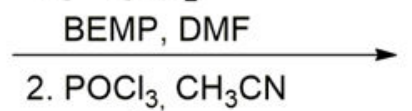

3.<smiles>C1CCNC1</smiles>

3<smiles>Nc1noc2ccccc12</smiles>

1. $\left[{ }^{11} \mathrm{C}\right] \mathrm{CO}_{2}$

C)

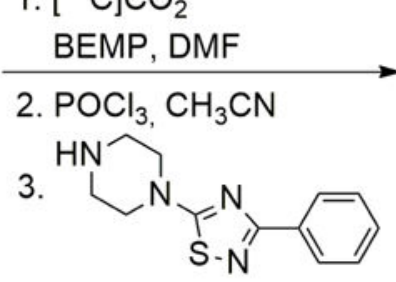

4<smiles>O=C(Nc1ccccc1)N1CCN(c2nc(-c3ccccc3)ns2)CC1</smiles>

$\left[{ }^{11} \mathrm{C}\right] 5, \mathrm{JNJ} 1661010$

6

4<smiles>O=C(Nc1noc2ccccc12)N1CCN(c2nc(-c3ccccc3)ns2)CC1</smiles>

Scheme 1.

Compounds radiolabelled at room temperature using the "in-loop" $\left[{ }^{11} \mathrm{C} \mathrm{CO}_{2}\right.$-fixation module. 

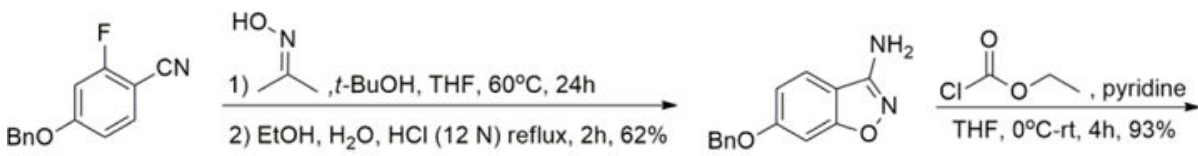

13
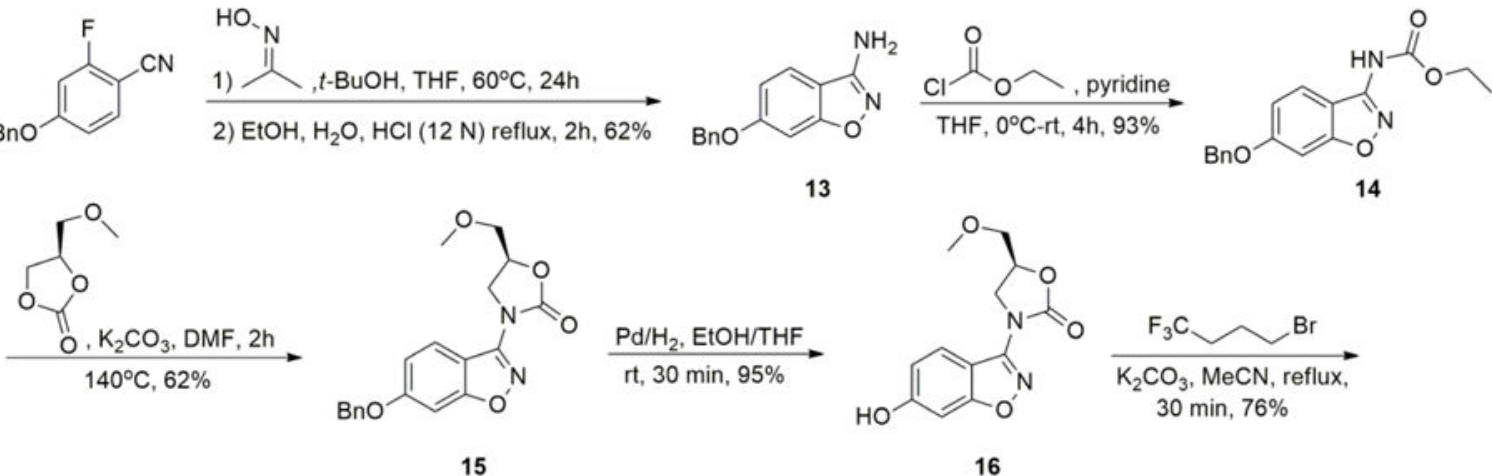

14

15

16
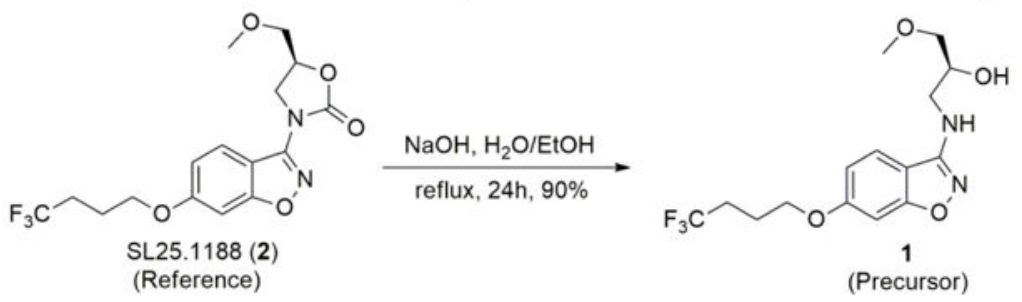

Scheme 2.

Synthesis procedure for compounds $\mathbf{1}$ and $\mathbf{2}$. 


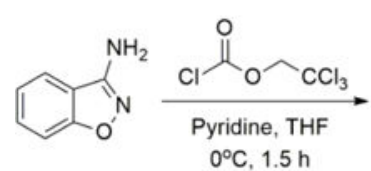

6

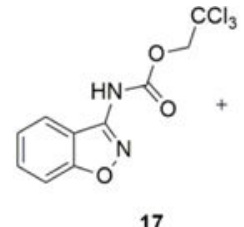

17

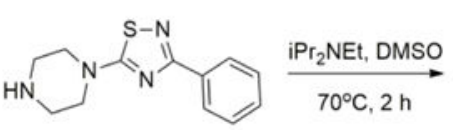

4

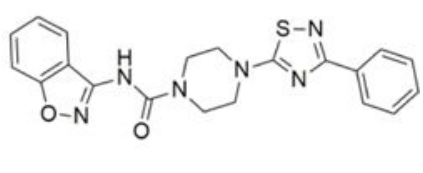

Scheme 3.

Synthesis procedure for compound 7. (32\% yield over 2 steps). 


\section{Table 1}

"In-loop" formation of $\left[{ }^{11} \mathrm{C}\right] 11$ and $\left[{ }^{11} \mathrm{C}\right] 12$

\begin{tabular}{|c|c|c|c|c|}
\hline Entry & Benzylamine (8) ( $\mu \mathrm{mol})$ & Trapped $\left[{ }^{11} \mathrm{C}\right] \mathrm{CO}_{2}(\%) c$ & RCY of $\left[{ }^{11} \mathrm{C}\right] 11(\%)^{d}$ & RCY of $\left[{ }^{11} \mathrm{C}\right] 12(\%)^{d}$ \\
\hline${ }_{1} b$ & 4.6 & $>99$ & $98 \pm 1^{h}$ & - \\
\hline $2^{a}$ & 4.6 & $>99$ & 16 & 68 \\
\hline $3^{a}$ & 1.3 & $>99$ & 37 & 46 \\
\hline $4^{a}$ & 0.6 & $>99$ & 52 & 29 \\
\hline $5^{a}$ & 0.3 & $>99$ & $83 \pm 2^{h}$ & 4 \\
\hline $6^{a}$ & 0.15 & $>99$ & 70 & 1 \\
\hline $7^{a, e}$ & 0.3 & $>99$ & 91 & 4 \\
\hline $8^{a, f}$ & 0.3 & $>99$ & 2 & 10 \\
\hline $9^{a, g}$ & 0.3 & $>99$ & 13 & 52 \\
\hline
\end{tabular}

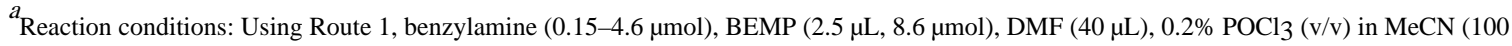
$\mu \mathrm{L}, 1.1 \mu \mathrm{mol}), 50 \% \mathrm{MeOH}(\mathrm{v} / \mathrm{v})$ in DMF $(50 \mu \mathrm{L}, 1.2 \mathrm{mmol})$.

${ }^{b}$ Using Route 2, with $10 \%$ iodomethane (v/v) in $\mathrm{MeCN}(100 \mu \mathrm{L})$ as alkylating agent.

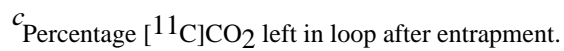

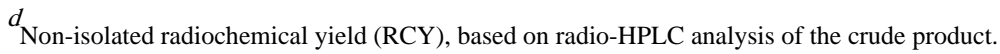

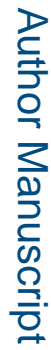

$e_{\mathrm{MeCN}}$ was used as solvent.

$f$ DMSO was used as solvent.

$g_{\text {DBU was used as fixation base. }}$

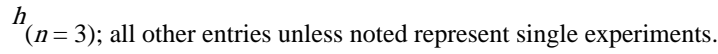




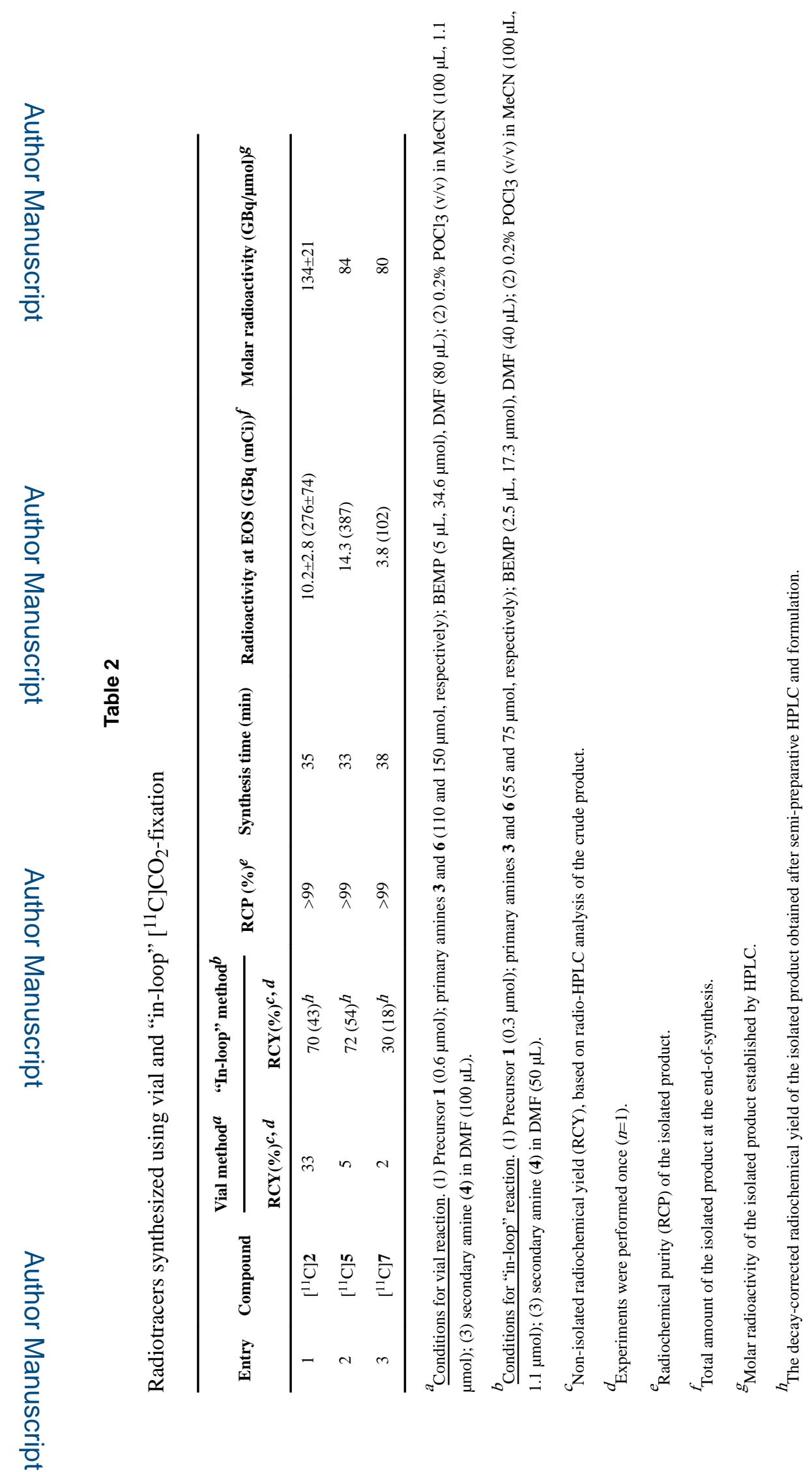

J Labelled Comp Radiopharm. Author manuscript; available in PMC 2018 March 28. 